\title{
INVESTMENTS IN LATVIA
}

\author{
SANDRA JeKABSONE ${ }^{1}$, IRINA SKRIBANE ${ }^{2}$
}

University of Latvia (Latvia)

\begin{abstract}
The effective attraction of investments to the national economy is a key factor, which provides favourable conditions to perform structural changes in the national economy, regional development as well as promotes technical progress. Therefore, investments in the public and the private sectors conduce development of the national economy and provide conditions to increase the overall competitiveness of a country. The purpose of research is to evaluate investment processes in Latvia before and after the global financial crisis, revealing investment-related problems. Also, to calculate the level of the desired investment, which would ensure the Latvia's average GDP growth of 5\% per year, according to the target set by the NDP. The analysis employs different qualitative and quantitative analysis methods, such as: scientific literature and empirical research analysis, modelling tables, charts and schemes, calculations of average and relative values, grouping, comparison and other. Publications on investment and research by Latvian and international scholars are analysed seeking to define the investment role on the economic growth process. The authors use the data available in the Central Statistical Bureau of the Republic of Latvia and Eurostat data bases, reports by the Ministry of Economics of the Republic of Latvia, the World Bank, the OECD and other studies of international organizations, as well as information provided in the Internet. As a result of research there have been defined the investment policy directions and essential obstacles that delay investment attraction in Latvia.

KEYWORDS: investments, investment gap, “optimal” level of capital, investment policy.
\end{abstract}

JEL CODES: E01, E22, E32, E60.

DOI:

\section{Introduction}

Nowadays a prerequisite of successful economic development is implementation of proper production assets and technologies, based on the latest scientific achievements, as well as development of infrastructure, which cannot be done without investments. Investments in the Latvian economy declined significantly due to the financial crisis, reaching $19.4 \%$ of GDP in 2010, which was almost twice lower than in 2007 . With the stabilization of the economy, investment has increased, but is still lower than was before the crisis, and in 2016 it reached $18.3 \%$ of GDP (CSP database, 2017).

Latvia continues to make steady economic progress, but growth seems to be settling at a more modest pace. Investment tendencies in Latvia have raised a number of interconnected problems such as: Is the current investment level too low? What is the "optimal" level of capital and how big is the investment gap? In the economy, investments are very sensitive to cyclical fluctuations (Investment in the OECD, 2015: 4). At the development stage of the economic cycle, investments are growing faster than GDP and their level increases. However, during the economic recession, they are rapidly shrinking, intensifying the GDP decline. Therefore, the level of investment (whether low or high) is a relative value that can be measured only under certain conditions. For example, seeking to find out in which stage of the cycle is currently the economy, or to define

\footnotetext{
Sandra Jekabsone - University of Latvia, Faculty of Business, Management and Economics, Department of Economics E-mail: sandra.jekabsone@lu.lv Tel. +371 26172296

2 Irina Skribane - University of Latvia, Faculty of Business, Management and Economics, Department of Economics E-mail: irina.skribane@1u.lv Tel. +37128370696
} 
concrete criteria (or indicative indicators), e.g., which level of investment is "normal" to the given cycle, or which level of investment would be "preferable" to ensure convergence with the highly developed countries.

The purpose of research is to evaluate the investment processes in Latvia before and after the global financial crisis, revealing investment-related problems, as well as to calculate the level of desired investment, which would ensure the Latvia's average GDP growth of 5\% per year, according the target set by the NDP.

The research object is pre- and post-crisis developments of investment in Latvia.

Tasks:

- To explore the dynamics of investment before and after the global financial crisis;

- To carry out a qualitative and quantitative analysis of the investment structure in Latvia;

- To identify the main factors influencing investment and sources of financing;

- To evaluate the "optimal" level of capital and investment gap in Latvia.

Methods. In this research, based on theoretical knowledge, there has been carried out qualitative and quantitative analysis on the dynamics and structure of the investment amount, and on the factors, that influence it. Calculations were also made to determine the optimal level of capital or investment in Latvia, and investment gap. In addition, there have been also evaluated the capital-output ratios with the steady-state condition.

\section{The role of investment in the economy}

Investment is a key factor in short- and long term economic development. The amount and quality of investments characterise the possibilities of economic development and the potential of economic development in the future, as well as define the increase of GDP, employment and income. First, investments are primarily inputs into resources that increase the productive potential of a country and possibility to provide the long term economic growth. Second, investment is one of demand factors and the components of GDP (expenditure side), therefore, it directly affects the current year's GDP growth rate. Third, the technological and sectoral structure of investments largely defines the effective use of resources and productivity growth (Eglīte, Skribāne, 2007: 133). Firms invest in new machinery, computers, R\&D, office buildings and plants, as well as in inventories to be sold at a future date. Most investment goods enable future production. If effective, investments increase the capital stock and thus the productive capacity of the economy (Investment in the OECD, 2015: 4). According to J. M. Keynes' concept, the decline in investments is the main cause of the decline in the economic activity, as it results in the narrowing of production, the growth of unemployment, and a decrease in the income of the population, and thus also in private consumption, as well as national budget revenues (Titarenko, 2008: 52). Investment is critical to sustaining the longterm growth. Capital accumulation raises labour productivity, a key driver of the long term growth of real wages and household incomes, not only by capital deepening — equipping workers with more capital — but often also by embodying productivity enhancing technological advances. As noted by many authors (Banerjee, Kearns, Lombardi, 2015; Bussiere, Ferrara, Milovich, 2016; Leboeuf, Fay, 2016; Ollivaud, Guillmette, Turner, 2016), the weak post crisis investment growth has contributed to the lower potential output growth from pre-crisis rates.

Therefore, the efficient attraction of investments in the national economy is decisive for the creation of favourable conditions to overcome situations of economic crisis, and for promoting regional development and technical progress, which, in their turn, are the foundation of the stable economic growth.

\section{Investment dynamics and structure in Latvia}

Investment in the economy of Latvia has been rather unstable since 2008. The decrease of investments during the crisis period was four times higher than in the EU on average and in 2010 it was by $63 \%$ lower than before the crisis (Eurostat Database, 2017). Over the last five years (2012-2016), investments amounted to $22 \%$ of GDP on average, which is almost by four percentage points less than in the period from 2000 to 2004, and almost by percentage points in the lower stage if compared to the rapid growth years (2005-2007). The overall total activity of investors after the global financial crisis has been low and contribution of investments to the increasing GDP fell short of pre-crisis level (see Figure 1). 


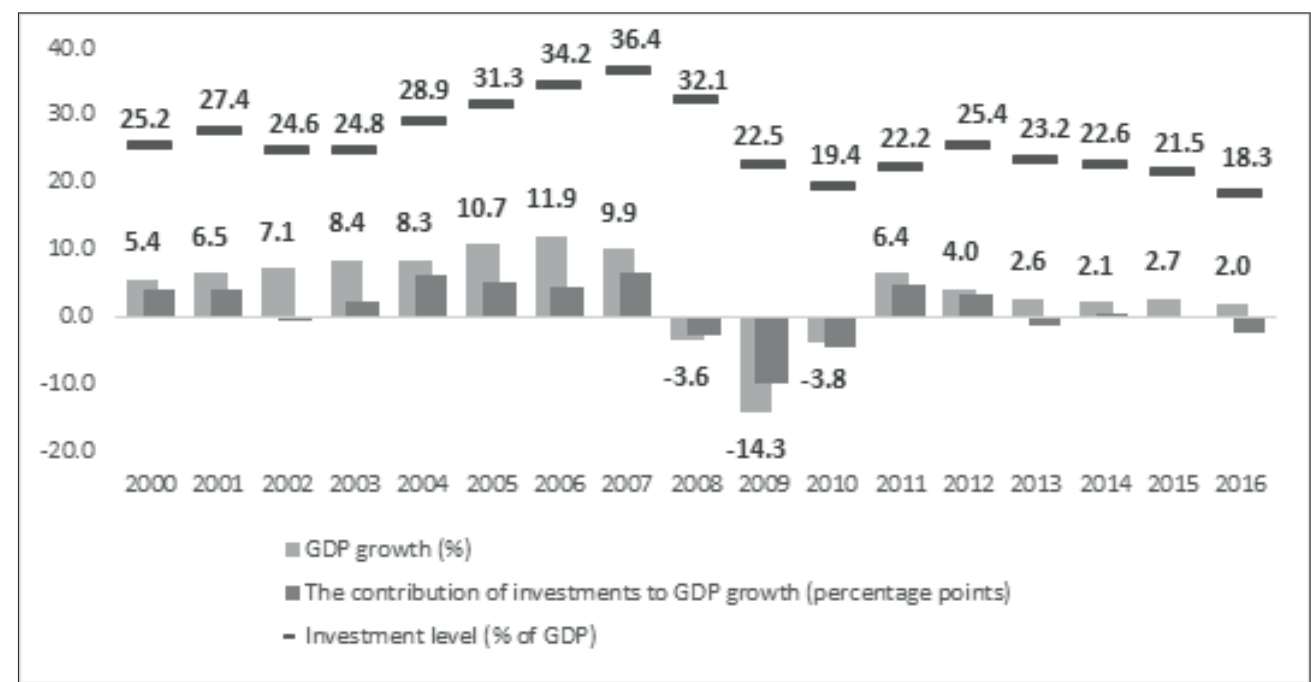

Fig. 1. Level of investment and contribution to GDP growth

Source: calculated by the authors based on CSB databases.

The relatively low level of investment is mainly due to the sharp decrease in private investment in the crisis years and the slow recovery in the post-crisis period. As shown in Figure 2, between 2012 and 2016, private investment amounted to $17.7 \%$ of GDP on average, which is twelve percentage points lower than in the fast-developing years (2005-2007), and also by six percentage points lower than in the period prior to Latvia's accession to the EU (2000-2004).

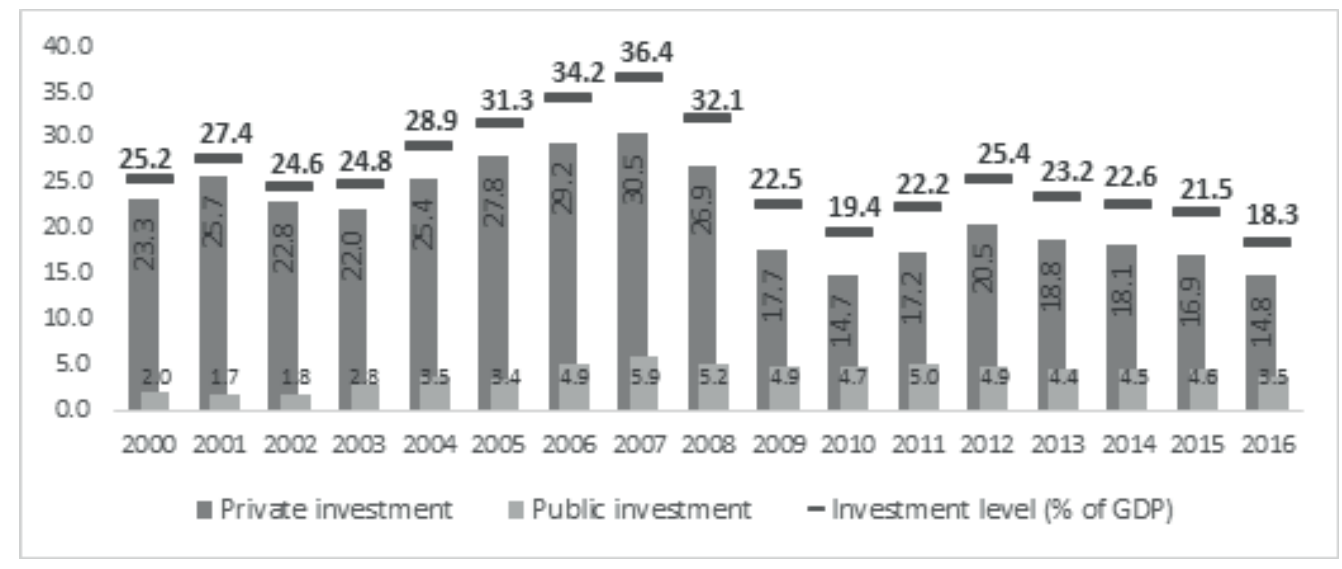

Fig. 2. Private and public investments in Latvia (\% of GDP)

Source: calculated by the authors based on CSB databases.

The decline in private investment was significantly influenced by household investment in housing, which reached almost $7 \%$ of GDP in the pre-crisis years (23\% of private investments). The share of household investment in recent years has been around $2.5 \%$ of GDP or $15 \%$ of private investments (see Figure 3).

In the majority of the EU countries, private investment does not exceed the pre-crisis level, and in Latvia, the backwardness of private investment is the greatest (see Figure 4). 


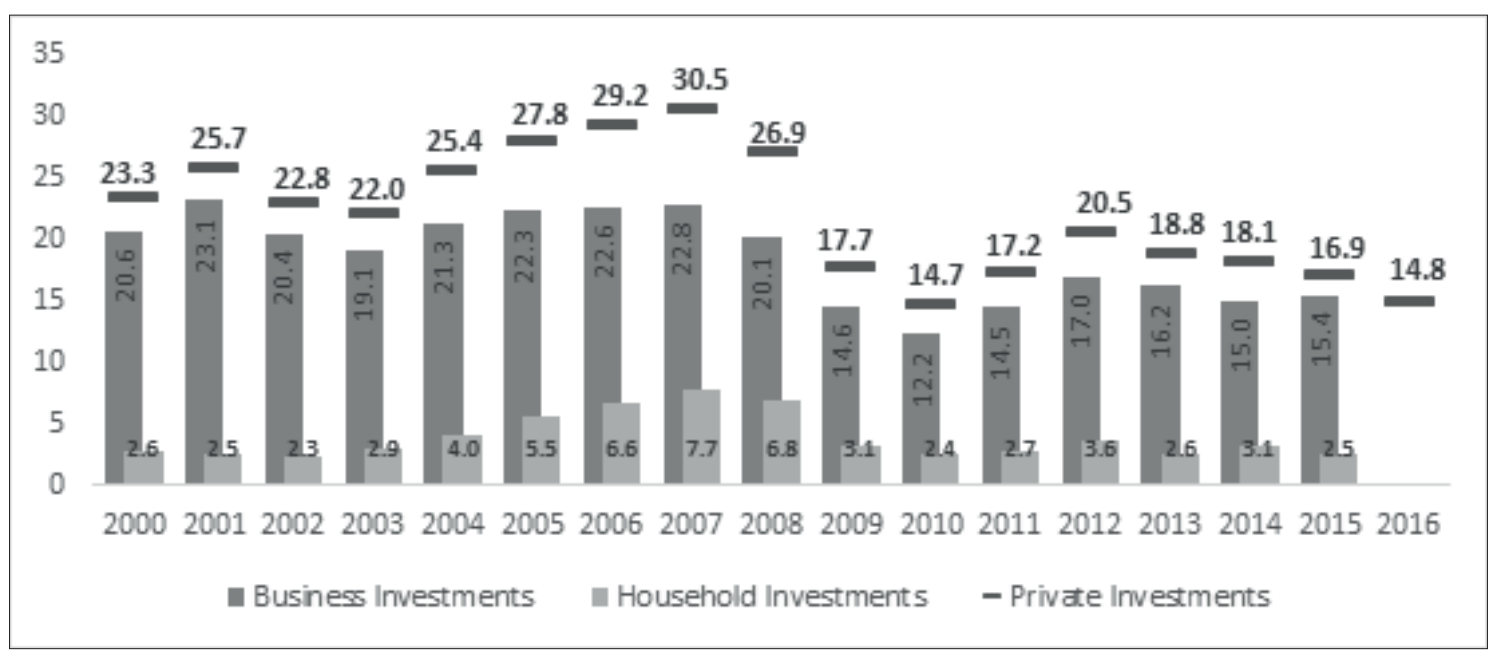

Fig. 3. Private investment level and structure (\% of GDP)

Source: calculated by the authors based on CSB databases.

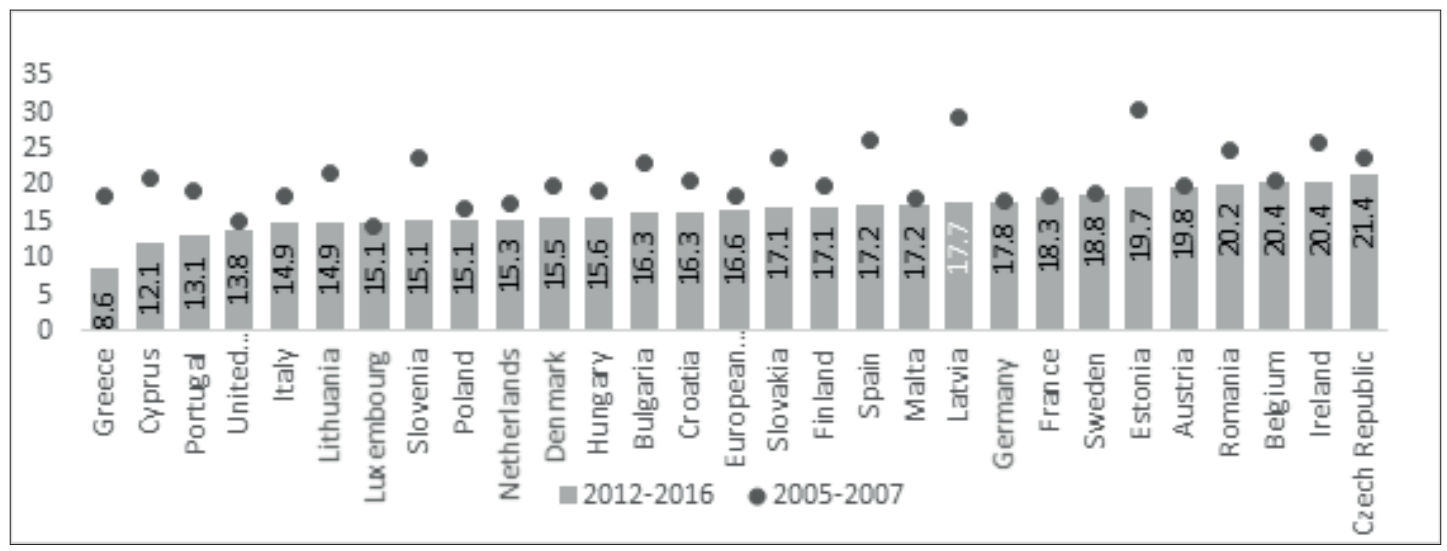

Fig. 4. Level of private investment in the EU Member States before and after the crisis (average in year, \% of GDP)

Source: calculated by the authors based on CSB databases.

Public investment in Latvia remained at a high level (4.5\% of GDP on average), partly offsetting the decline in private investment. Public investment in recent years forms almost $1 / 5$ of the total investment. In Latvia, the level of public investment is one of the highest among the EU Member States, where the leading position has Estonia - 5.4\% of GDP. It should be noted that in the old EU Member States, public investment forms averagely $2.8 \%$ of GDP and remains at a slightly lower level than before the crisis (see Figure 5). Low levels of public investment, if maintained over a prolonged period, may lead to a deterioration of public capital and diminish longer-term output (ECB, 2016: 75).

By rating in terms of assets, the largest drop in investment in Latvia was due to investment in construction, which decreased by 10.8 percentage points of GDP (from 2007 to 2016). In addition, the investment drop in equipment (which is significant for future production) was slightly lower - by 7.2 percentage points of GDP. However, investment in intellectual property assets remained virtually unchanged, has remained at a low level for several years - averagely $1 \%$ from GPD, including investments in P\&A $-0.6 \%$ from GDP (see Figure 6). 


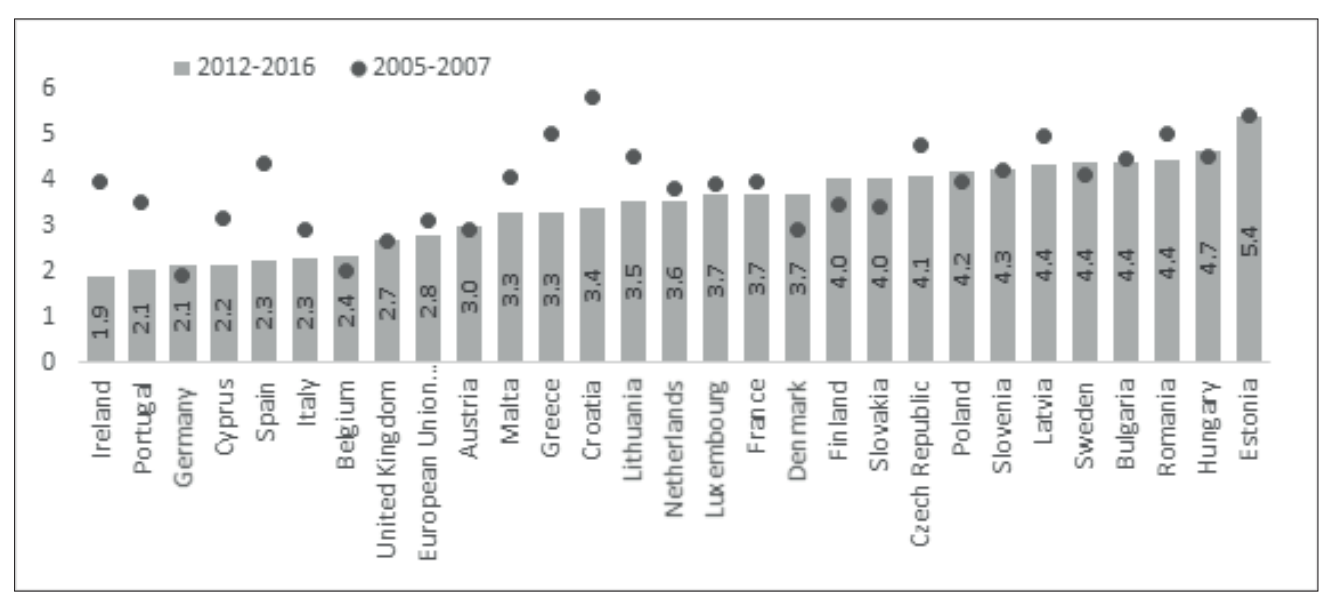

Fig. 5. Level of public investment in EU Member States before and after the crisis (average per year, \% of GDP)

Source: calculated by the authors based on CSB databases.

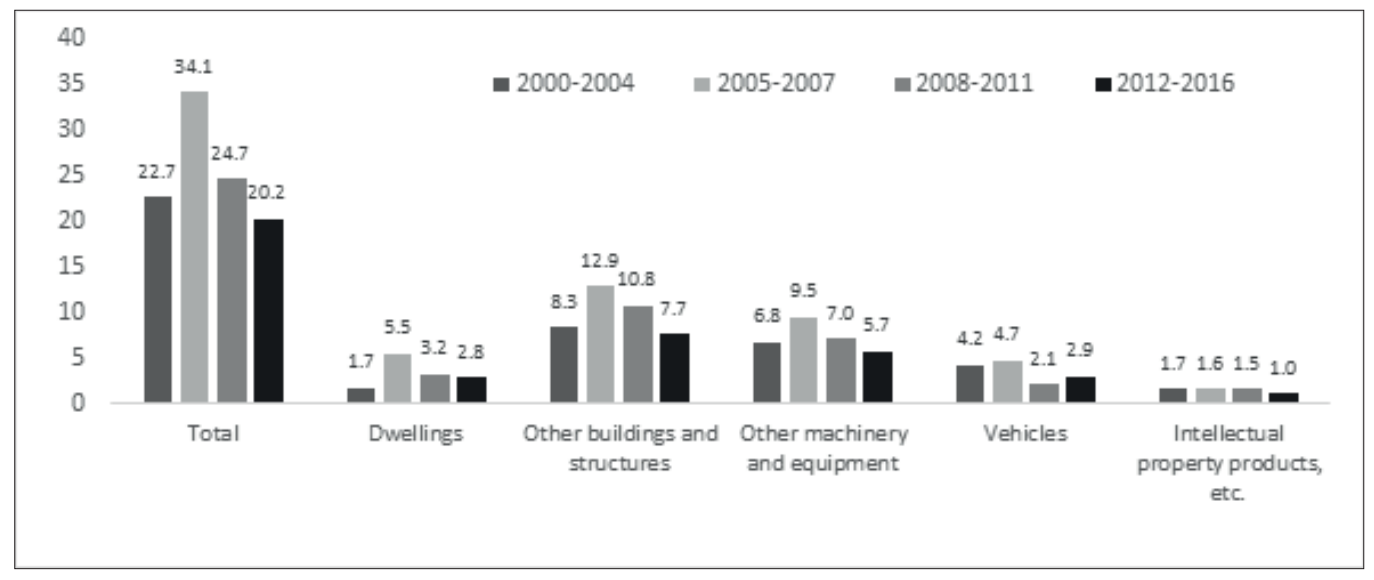

Fig. 6. Investment by type of assets (\% of GDP)

Source: calculated by the authors based on CSB databases.

Investment in infrastructure and housing construction forms a larger share of average domestic investment. Therefore, their reduction in the years of crisis and the slow recovery in the post-crisis period had the greatest negative impact on the total investment level in the country. Investments in the improvement of the Latvian infrastructure were mostly financed from the EU structural funds and the state budget. Therefore, their further growth will largely depend on the restoration of financing of the ESF programmes as well as on the fiscal space borders of the state budget. Investment in housing is unlikely to increase substantially in the near future. Its funding is mainly bounded to the volumes of mortgage lending, which are currently low, and their dynamics is weak. The growth of investment in housing is also limited by the relatively high level of household indebtedness. In recent years, machinery and equipment investments formed averagely $8.7 \%$ of GDP, the lowest since the year 2000. Investments in these assets are closely related to the business environment and the state of affairs. According to the results of the survey of entrepreneurs, the growth of investments is substantially limited by low demand. As far as investments in intellectual property products are concerned, their growth will be determined not only by the availability of funding (innovation support instruments), but also by the demand of entrepreneurs to a large extent, i.e., the desire to increase innovative activities with a view to improving competitiveness. 


\section{The "optimal" level of capital and investment gap in Latvia}

Both in theoretical (Clark, Cobb-Douglas, Harod-Domar) and in empirical models, there has been approved that the rapid economic growth is not possible without significant investments (Jekabsone, Skribane, 2016: 303). Investments are contribution in non-financial assets and, as productive capacity makers, investments increase production capacity by promoting productivity levels and growth. Latvia lags the EU countries in various investment-related respects: it has the lowest capital-output ratio in the EU-28; and capacity utilization, despite having rebounded strongly since the crisis, is still lower than in the most EU countries. Therefore, higher investment rates and modernization of the capital stock are key to raising the potential medium-term growth. To ensure the stable economic growth in a long period, there are required investments in the amount of 25-30\% of GDP (Latvijas ekonomikas, 2009: 28). The impact of investments on GDP growth can be viewed from several aspects. First of all, investments are one of the components of the use of GDP, therefore their level and dynamics influence the annual GDP growth rates. However, it should be noted that not always the high volume of investments was reflected in GDP growth. As Figure 1 shows, in Latvia, GDP growth has been quite different at a relatively similar level of investment. However, when reaching a high level of investment, their contribution to GDP growth may be rather small. It depends on several circumstances. For example, if production equipment is imported, the contribution of the investment growth to GDP growth will be reduced by the growth of imports and the increase of the external trade deficit. According to some authors (D. Paula, D. Titarenko, D. Stikuts, A. Melihovs, O. Krasnopjorovs and others) contribution of investments to increasing GDP in the last ten years in Latvia has been 46.5\% up to 85\% ((Jekabsone, Skribane, 2016: 304).

According to the classical growth theory, the level of private investment depends on the extent to which the existing accumulated share capital (production capacity) corresponds to the current output (demand) level, which is called the "optimal" capital stock (Saltari, Travaglini, 2011: 4). In conditions of weak conjuncture, low-capacity production constrains investors' willingness to implement investment plans. Of course, concrete policy measures can stimulate the implementation of investment plans and increase the level of investment in the country during a given period, but it is likely to have a short-term effect. With the weakening of the economy, the investment growth will be offset by lower investment levels in the coming years. The world experience has shown that the level of investment artificially maintained above the "optimal" level of capital can lead to the accumulation of non-performing loans in the banking sector.

It is obvious that the dynamics and level of investment in the last years before the crisis was too high and thus cannot serve as an indicative indicator for assessing the current level of investment. Any comparison with the maximum level achieved in 2007, i.e., lending at historically high levels, is not applicable. However, the current level of investment is likely to remain below the "normal" levels before the lending's rapid growth. Therefore, historically, and taking into account the current level of the Latvian economy development, investment should be at least 25\% of GDP. According to such assumptions, the investment gap over the past five years can be estimated at 3\% of GDP.

Another question is, will the existing accumulated share capital (production capacity) in Latvia be consistent with the current output (demand) level? One of the indicators of capital adequacy to output level is the production capacity utilization. In recent years, the capacity of the Latvian industry as a whole has increased, reaching $74 \%$ by the end of 2016, which corresponds to the pre-crisis level (see Figure 7).

Assessing the current state of industry, it should be concluded that, at the current conjuncture and also relatively low credit rates, investments are relatively low and there is a need to deeply investigate the factors limiting investments at the sectoral level. In general, in macroeconomic terms, low levels of investment and weak dynamics are largely influenced by weak lending, relatively low demand, relatively high levels of private and public debt, and the uncertainty surrounding the external environment of the economic and political situation.

The country's current level of investment can also be analysed in the context of the long-term growth by assessing the compliance of the capital-output ratios with the steady-state. In recent years, the coefficient of capital, i.e., output ratios, in Latvia was on average 1.0, which is one of the lowest in the EU (AMECO databases, 2017). However, given that Latvia is a middle-income country, the capital-output ratio can be considered to be lower than its steady-state level. Our calculations show that to reach the annual GDP growth of 5\%, according 
to the target set by the NDP (Latvijas Nacionālais attīstības plāns, 2012) investment must be at least $25 \%$ of GDP. At the same time, it should be noted that the level indicator of the accrued capital may also be false if it has a high proportion of assets that are weakly related to the production process (for example, real estate). Therefore, assessing the level of "normal" investments in the country in relation to the growth rates of GDP, an incorrect result may arise, for example, that the growth rates can be achieved with a relatively higher level of investment.

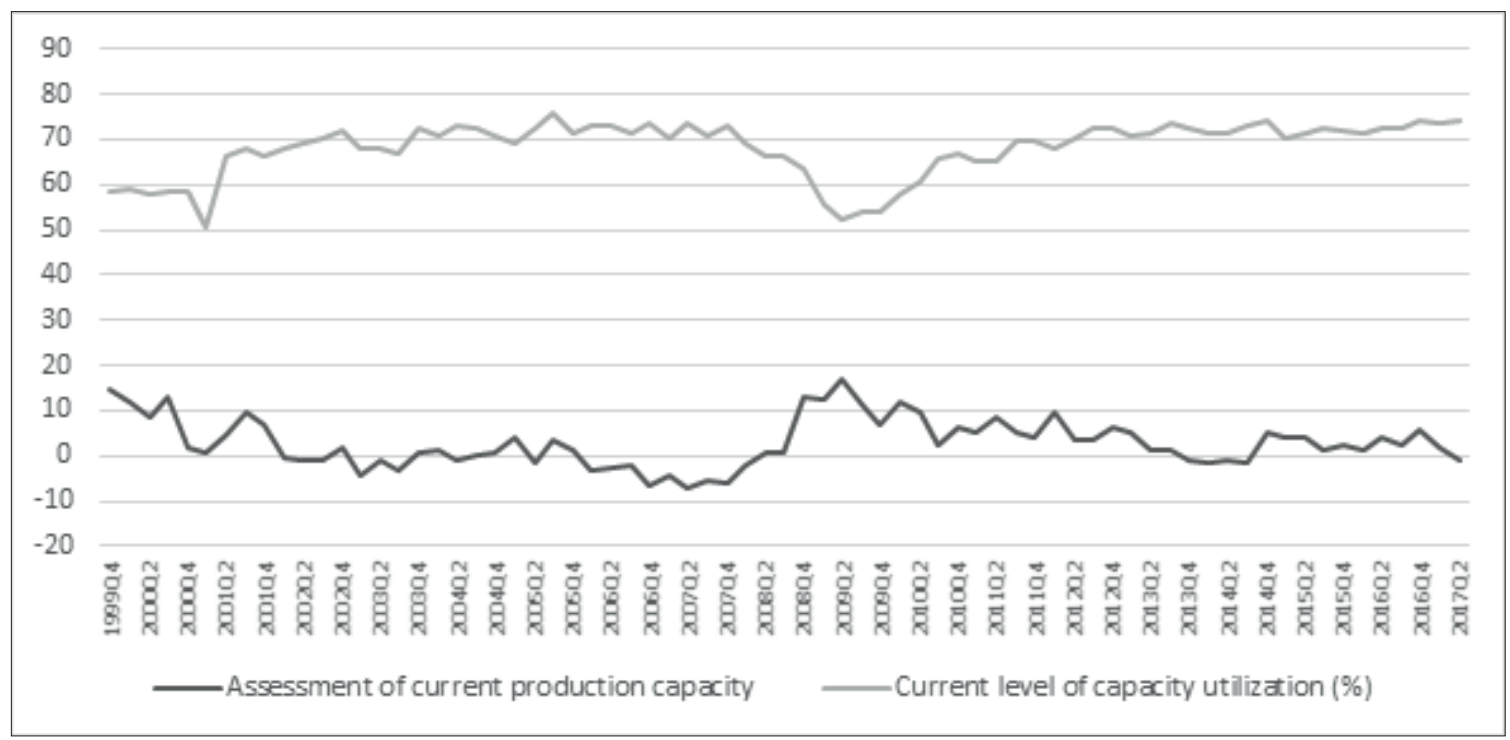

Fig. 7. Capacity level of production and capacity adequacy

Source: calculated by the author based on the data from Eurostat databases.

\section{Conclusions}

Investment activity in Latvia is quite moderate and the contribution of investments to GDP growth is insignificant. In the year 2016, investment was $18.3 \%$ of GDP, the lowest since the year 2000. On the other hand, over the last five years (2012-2016), investments amounted to, on average, 22\% of GDP, which is almost twelve percentage points lower than in the fast-development years (2005-2007). Remaining the following trends in the future might decrease production capacity and competitiveness of Latvia in the World Market.

The low level of investment and weak dynamics are largely influenced by weak lending, relatively low demand, relatively high levels of private and public debt, and the uncertainty surrounding the economic and political situation in the external environment.

The level of investment (whether it is low or high) is a relative value that can be measured only under certain conditions, e.g., such as the current economy's stage in a phase of the cycle, and by the definition of specific criteria (or indicative indicators), such as the level of investment "preferable" to ensure convergence with the highly developed countries.

The level of investment that was achieved in the last years before the crisis cannot serve as an indicative indicator for evaluating the current level of investment, as it was achieved at the level of the historically maximum lending.

However, from a historical point of view, also taking into account the current level of the Latvian economy development, investment should reach at least $25 \%$ of GDP. Based on these assumptions, the overall investment gap over the past five years can be estimated at 3\% of GDP.

At present, investments in all assets are lower than in the pre-crisis years. However, the factors determining the growth of investment in various assets are quite different and are only partly related to the lack of access to finance. 
Investments in construction-related assets will be mainly facilitated by expanding the availability of ESF financing as well as by the renewal of mortgage lending. However, the size of the state budget, as well as the capacity of construction organizations may limit the investment growth in construction assets.

Increase of investments in intellectual property products will be determined not only by the availability of financing (innovation support instruments), but also by the demand of entrepreneurs, i.e., the desire to increase innovative activities with a view to improving competitiveness.

Assessing the current state of industry, it should be concluded that, at the current situation, investment in production equipment and machinery is relatively low, as well as are relatively low credit rates. Their growth will be most determined by the improvement of conjuncture and the decrease of geopolitical uncertainty.

Specific policy measures can stimulate the implementation of investment plans and increase the level of investment in the country during a given period. However, remaining the current low state of affairs, the artificially stimulated investment growth will be offset by a lower level of investment in the coming years. The world experience has shown that the level of investment artificially maintained above the "optimal" level of capital can lead to the accumulation of non-performing loans in the banking sector.

\section{References}

AMECO database (2017). Available at: https://ec.europa.eu/info/business-economy-euro/indicators-statistics/economic-databases/macro-economic-database-ameco/ameco-database_en.

Banerjee, R., Kearns, J., Lombardi, M. (2015). (Why) Is Investment Weak? BIS Quarterly Review, March, p. 67-82.

Bussiere, M., Ferrara, L., Milovich, J. (2016). Explaining the Recent Slump in Investment: The Role of Expected Demand and Uncertainty. IMF Research Bulletin, No. 17.

CSP database. (2017). Available at: http://www.csb.gov.lv/.

ECB Economic Bulletin, Public Investment in Europe. Issue 2 / 2016. (2016). Available at: https://www.ecb.europa.eu/ $\mathrm{pub} / \mathrm{pdf} / \mathrm{ecbu} / \mathrm{eb201602.en.pdf}$

Eglīte, S., Skribāne, I. (2007). The Competitiveness of Investments' Environment in Latvia, Information Society and Modern Business. Conference on 1-2 July 2005, Ventspils / Head of editorial board, S. Hilkevics. Conference organizers: Ventspils University College, Ventspils City Council. Ventspils: Ventspils University College, 2007.

Eurostat Database. (2017). Available at: http://epp.eurostat.ec.europa.eu.

Harada, T. (2012). Structural Change and Economic Growth with Relation-Specific Investment. Structural Change and Economic Dynamics, Vol. 32, p. 1-10. Available at: http://doi.org/10.1016/j.strueco.2014.12.002.

Informatīvais zinojums "Par Latvijas preču un pakalpojumu eksporta veicināšanas un ārvalstu investīiju piesaistes pamatnostādņu 2013.-2019. gadam istenošanas 2013.-2015. gadā starpposma novērtējumu”" (2016). LR EM, Rìga, 2016.

Inovācijas un Latvijas tautsaimniecība. (2011). Monogrāfija. Rīga, LU Akadēmiskais apgāds: Latvijas Universitāte.

Investment in the OECD: Pre- and Post-Crisis Developments. (2015). CPB Netherlands Bureau for Economic Policy Analysis, May 18th.

Jēkabsone, S., Skribane, I. (2016). Impact of the Crisis on Investment: Latvian Investment Policy Problems, CIU: International Scientific Conference, Tbilisi, $11^{\text {th }}-13^{\text {th }}$ November, 2016. Full Papers Tbilisi, p. 302-310.

Latvijas ekonomikas konkurētspēja un investīciju nozīme tās veicināšanā. (2009). Monogrāfija. E. Dubras redakcijā. LU Akadēmiskais apgāds.

Latvijas investīciju un attīstības aǵentūra. (LIAA) (2017). Investīcijas. Available at: http://www.liaa.gov.lv/lv/investicijas/investiciju-piesaiste.

Leboeuf, M., Fay, B. (2016). What is Behind the Weakness in Global Investment? Staff Discussion Paper 5. Bank of Canada, Ottawa.

Valsts investīciju politikas īstenošanas procesa Latvijā novērtējums. Pētījuma galazinojums. (2005). Available at: http://petijumi.mk.gov.lv/sites/default/files/file/EMpet_2005_Valsts\%20investiciju\%20politikas\%20novertejums_ gala\%20zin.pdf.

Latvijas Nacionālais attīstības plāns 2014.-2020. Gadam. (2012). Available at: https://likumi.lv/doc.php?id=253919.

National Reform Programme of Latvia for the Implementation of the "Europe 2020" Strategy. (2011). Available at: http://www.em.gov.lv/images/modules/items/LV_NRP_lat.pdf

Pashev, K., Casini, P., Kay, N., Pantea, S. (2015). EU Structural Change. Available at: http://www.industria.ejgv.euskadi. eus/contenidos/informacion/liburutegia_berriak_aipagarrie/eu_liburute/adjuntos/EU_strutural_change_2015.pdf.

Ollivaud, P., Guillemette, Y., Turner, D. (2016). Links Between Weak Investment and the Slowdown in Productivity and Potential Output Growth Across the OECD. Working Paper 1304. Organisation for Economic Cooperation and Development. Paris. 
Report on the Economic Development of Latvia. (2016). Ministry of Economics. Riga, June.

The National Economy of Latvia: Macroeconomic Review. (2016). Ministry of Economics, Riga, \#69 2016-4.

Saltari, E., Travaglini, G. (2011). Optimal Capital Stock and Financing Constraints. MPRA Paper, No. 35094.

Titarenko, D. (2006). Investīcijas kā Latvijas ekonomikas izaugsmes factors. Rīga: Transporta un sakaru institūts.

Titarenko, D. (2008). Investments as a Growth Factor of the Latvian Economy. MPRA Paper, No. 16775. University of Latvia.

Екабсоне, С., Скрибане, И. (2015). Влияние макроэкономических корректировок на долгосрочный экономический рост Латвии. 43-я Международная научно-практическая конференция для студентов, аспирантов и молодых ученых „Конщептуальное развитие экономических наук в 21-м веке“, 18 декабря, 2015 г.: сборник научных публикащий. Москва: Аналитический центр „Экономика и финансы“.

\section{NVEST I C I JOS LATVIJOJE}

SANDRA JEKABSOne, Irina SKRIBAnE

Latvijos universitetas (Latvija)

\section{Santrauka}

Nuo pasaulio finansų krizès pradžios investicijų lygis Latvijoje išlieka žemas, tai riboja ekonomikos augimą. Atliekant tyrimą siekta ịvertinti investavimo procesus Latvijoje prieš ir po pasaulinės finansų krizės, atskleisti su investicijomis susijusias problemas, apskaičiuoti pageidaujamų investicijų lygị, kuris užtikrintų, kad Latvijos BVP augtų vidutiniškai 5 \% per metus. Atlikus investavimo procesų analizę, nustatytos pagrindinès investicijų augimo kliūtys ir investicijų skatinimo politikos kryptys. Analizei atlikti taikyti ịvairūs kokybiniai ir kiekybiniai metodai (literatūros ir empirinių tyrimų analizè, modeliavimas, diagramos ir schemos, vidutinių ir santykinių verčių skaičiavimas, grupavimas, palyginimai ir kt.). Autorès, siekdamos pagrịsti tyrimo rezultatus, rèmėsi Latvijos centrinio statistikos biuro, EUROSTAT, Latvijos ekonomikos ministerijos ir Pasaulio Banko duomenimis. Investavimo lygis Latvijoje yra gana vidutiniškas, o investicijų indèlis ị BVP augimą - nereikšmingas. 2016 metais investicijos siekè 18,3 \% BVP, tai mažiausias investicijų indẻlis nuo 2000 metų. Nustatyta, kad neaukštą investavimo lygi ir menką dinamiką lemia silpnas kreditavimas, santykinai maža paskolų paklausa, santykinai aukštas privataus ir valstybinio skolinimosi lygis ir neapibrèžtumas, susijęs su ekonomine bei politine išorès aplinkos padėtimi. Nustatyta, kad konkrečios politikos priemonės gali skatinti investicijų planų iggyvendinimą ir didinti investicijų lygi šalyje per tam tikrą laikotarpị. Tačiau, esant dabartinei ekonominei padéčiai (kai ekonomikos augimas yra žemas), dirbtinai skatinamą investicijų augimą kompensuoti gali mažesnès investicijos ateinančiais metais. Pasaulio patirtis parodè, kad gautos investicijos, siekiant dirbtinai išlaikyti aukštesnį nei „optimalus“ kapitalo lygị, gali paskatinti neveiksnių paskolų kaupimą banko sektoriuje.

PAGRINDINIAI ŽODŽIAI: investicijos, investicijų atotrūkis, ,optimalus“ kapitalo lygis, investavimo politika.

JEL KLASIFIKACIJA: E01, E22, E32, E60

Received: 2017.11.23

Revised: 2017.12.28

Accepted: 2018.01.18 